\title{
PENGARUH PERPUTARAN PERSEDIAAN, PERPUTARAN KAS DAN PERSEDIAAN PIUTANG RENTABILITAS EKONOMIS (STUDI PADA PERUSAHAAN MANUFAKTUR SUB SEKTOR FOOD AND BEVERAGES YANG TERDAFTAR DI BURSA EFEK INDONESIA TAHUN 2012-2016)
}

\author{
Clara C. Runtunuwu ${ }^{1}$, Stanly W. Alexander ${ }^{2}$, Heince R. N. Wokas ${ }^{3}$ \\ 1,2,3 Fakultas Ekonomi dan Bisnis, Jurusan Akuntansi, Universitas Sam Ratulangi, Jl. Kampus Bahu, Manado, \\ 95115, Indonesia \\ E-mail : clararuntunuwu280695@gmail.com
}

\begin{abstract}
The purpose of this study to determine the effect of inventory turnover, cash turnover, and receivable turnover to economic profitability as measured by Return On Assets (ROA). Sample selection was done by purposive sampling method and from 16 manufacturing companies food and beverages sub sectors obtained 11 samples of the company. The data used is secondary data. This study analyzes the relationship between the number of inventory turnover, cash turnover, and receivable turnover to economic profitability as measured by Return On Assets (ROA). The statistical method used is multiple linear regression by doing the classical assumption test first. The results of this study show that partially variable inventory turnover significant effect on economic profitability measured by Return On Assets (ROA), cash turnover significant effect on economic profitability as measured by Return On Assets (ROA), and turnover receivables have no significant effect on profitability economic value as measured by Return On Assets (ROA) in manufacturing companies food and beverages sub sector listed in Indonesia Stock Exchange (IDX).

Keywords: Inventory turnover, Cash turnover, Receiveable turnover, Economic profitability, Return On Assets.
\end{abstract}

\section{PENDAHULUAN}

Di era globalisasi ini banyak sekali perusahaan-perusahaan yang didirikan termasuk di Indonesia, perusahaan-perusahaan yang bergerak dalam kegiatannyamasing-masing. Perkembangan itu semakin meningkat untuk memenuhi kebutuhan dari para konsumen dan akibatnya persaingan yang terjadi antara perusahaan semakin kompetitif, termasuk pada perusahaan manufaktur. Keadaan seperti ini setiap perusahaan senantiasa memperhatikan kondisi pasar dan prospek pasar sehingga perusahaan dapat memanfaatkan peluang yang ada untuk mendapatkan keuntungan. Perusahaan akan melakukan berbagai aktivitas untuk mencapai tujuannya yaitu mendapatkan keuntungan, menjaga kelangsungan hidup perusahaan dan pertumbuhan.

Dalam perusahaan manufaktur, investasi ke dalam aktiva dapat di lakukan pada persediaan, persediaan perusahaan manufaktur memiliki beberapa jenis berupa bahan baku (direct material), barang dalam proses (work in proses) dan barang jadi (finished goods). Persediaan merupakan suatu aktiva yang paling aktif dalam operasi perusahaan baik usaha kecil atau besar. Persediaan merupakan investasi yang dibuat untuk tujuan merencanakan tingkat optimal investasi persediaan dan mempertahankan tingkat optimal tersebut melalui persediaan itu sendiri.

Kesalahan dalam menetapkan persediaan akan perpengaruh langsung terhadap tingkat keuntungan perusahaan. Jika persediaan dalam suatu perusahaan kurang maka penjualan akan turun dibawah tingkat yang seharusnya dapat tercapai. Demikian sebaliknya dengan persediaan yang terlalu besar menghadapkan perusahaan pada biaya penyimpanan, pajak, beban bunga dan biaya asuransi. 
Selain persediaan pengelolaan kas yang baik mempengaruhi tingkat perputaran kasnya, hal ini menunjukan bahwa kegiatan operasional perusahaan berjalan dengan lancer. Kas sendiri merupakan aktiva paling likuid untuk dapat memenuhi kebutuhan dalam suatu perusahaan dalam hal ini perusahaan manufaktur, maka semakin tinggi kas dalam suatu perusahaan berarti perusahaan memiliki resiko yang lebih kecil untuk dapat memenuhi kewajiban finansialnya.

Selain diinvestasikan dalam bentuk persediaan dan kas, dana yang dimiliki oleh perusahaan juga dapat ditanamkan dalam bentuk piutang. Akun piutang merupakan salah satu komponen modal kerja yang penting dalam perusahaan. Piutang merupakan klaim atau tagihan yang dilakukan oleh perusahaan kepada pihak lain (pelanggan) yang diakibatkan karena adanya pembelian barang atau jasa secara kredit kepada perusahaan. Mengingat pentingnya bahwa piutang merupakan suatu bentuk investasi yang cukup besar dan mempengaruhi bagi perusahaan serta memberikan banyak manfaat bagi perusahaan, maka diperlukan pengelolaan piutang yang efektif dan efisien sehingga rentabilitas ekonomis perusahaan dapat meningkat. Pengelolaan piutang dalam suatu perusahaan menyangkut pada perputaran piutang. Semakin tinggi perputaran piutang, maka semakin meningkatnya rentabilitas ekonomis perusahaan karena jumlah piutang tak tertagih semakin kecil. Akan tetapi perputaran piutang yang terlalu tinggi dapat menurunkan rentabilitas ekonomis, hal ini dikarnakan dana yang tertanam dalam piutang terlalu kecil yang berarti volume penjualan kredit juga terlalu kecil dan rentabilitas ikut menurun (Rahayu \& Susilowibowo, 2014).

Setiap perusahaan penting untuk mengetahui tingkat rentabilitas ekonomisnya untuk mengukur kemampuan suatu perusahaan dengan seluruh modalnya yang ada untuk menghasilkan laba. Pengelolaan pada perputaran persediaan, perputaran kas dan perputaran piutang dalam suatu perusahaan akan sangat perpengaruh terhadap tingkat rentabilitas ekonomis suatu perusahaan. Ada beberapa alat ukur yang digunakan untuk mengukur tingkat rentabilitas ekonomis, antara lain : return on assets (ROA), return on investment (ROI), dan return on equity (ROE). Penelitian ini memfokuskan objek penelitian pada perusahaan manufaktur sub sektor food and bevarages yang terdaftar di Bursa Efek Indonesia. Obyek penelitian adalah perusahaan industri sub sektor food and beverages yang terdaftar di Bursa Efek Indonesia dengan alasan sub sektor food and beverages akan bertahan terhadap krisis di bandingkan dengan sektor lainnya, sebab dalam kondisi krisis ataupun tidak produk makanan dan minuman tetap dibutuhkan. Berdasarkan masalah yang telah diuraikan, maka tujuan dari penelitian ini adalah untuk mengetahuai pengaruh perputaran persediaan, pengaruh perputaran kas dan perputaran piutang terhadap rentabilitas ekonomis pada perusahaan Manufaktur Sub Sektor Food and Beverages yang terdaftar di Bursa Efek Indonesia Tahun 2012-2016.

\section{TINJAUAN PUSTAKA}

\subsection{Perputaran Persediaan}

Menurut Harrison Jr et al (2013: 260), Perputaran persediaan (inventory turnover) yaitu mengukur berapa kali perusahaan menjual tingkat rata-rata persediaannya selama satu tahun. Perputaran yang cepat menunjukan kemudahan dalam menjual persediaan, sementara perputaran yang rendah mengindentifikasi kesulitan dalam menjual persediaan.

\subsection{Perputaran Kas}

Menurut Rahayu dan Susilowibowo (2014) Perputaran kas adalah periode berputarnya kas yang dimulai pada saat kas diinvestasikan hingga kembali menjadi kas. Rasio perputaran kas merupakan perbandingan antara penjualan dengan kas rata-rata. Rasio ini berguna untuk mengetahui sampai seberapa jauh efektivitas perusahaan dalam mengelola 
dana kasnya untuk menghasilkan pendapatan atau penjualan. Angka rasio yang semakin tinggi akan semakin baik.

\subsection{Perputaran Piutang}

Rasio ini digunakan untuk mengukur berapa lama penagihan piutang selama satu periode atau berapa kali dana yang tertanam dalam piutang berputar dalam satu periode. Singkatnya, rasio ini menunjukan apakah sebuah perusahaan dapat menagih piutang atau penjualan (yang dilakukan secara kredit) secara efektif atau tidak Zufikar (2016:158).

\subsection{Rentabilitas Ekonomis}

Menurut Riyanto (2011:33) "Rentabilitas ekonomi ialah perbandingan antara laba usaha dengan modal sendiri dan modal pinjaman yang dipergukan untuk menghasilkan laba tersebut dan dinyatakan dalam presentase." Menurut Wadyudiono (2014:82) Rasio ini digunakan untuk mengukur kemampuan aktiva perusahaan memperoleh laba dari operasi perusahaan. Untuk pengukuran ini, biasanya laba dihitung adalah sebelum bunga dan pajak. Aktiva perusahaan dalam hal ini adalah aktiva operasional yang dihitung secara rata-rata.

\subsection{Penelitian Terdahulu}

Penelitian terdahulu ini menjadi salah satu acuan peneliti dalam melakukan penelitian sehingga peneliti dapat memperkaya teori yang dapat digunakan dalam mengkaji penelitian yang dilakukan peneliti yaitu

\subsection{Kerangka Pemikiran}

Gambar 2.1

Kerangka konseptual

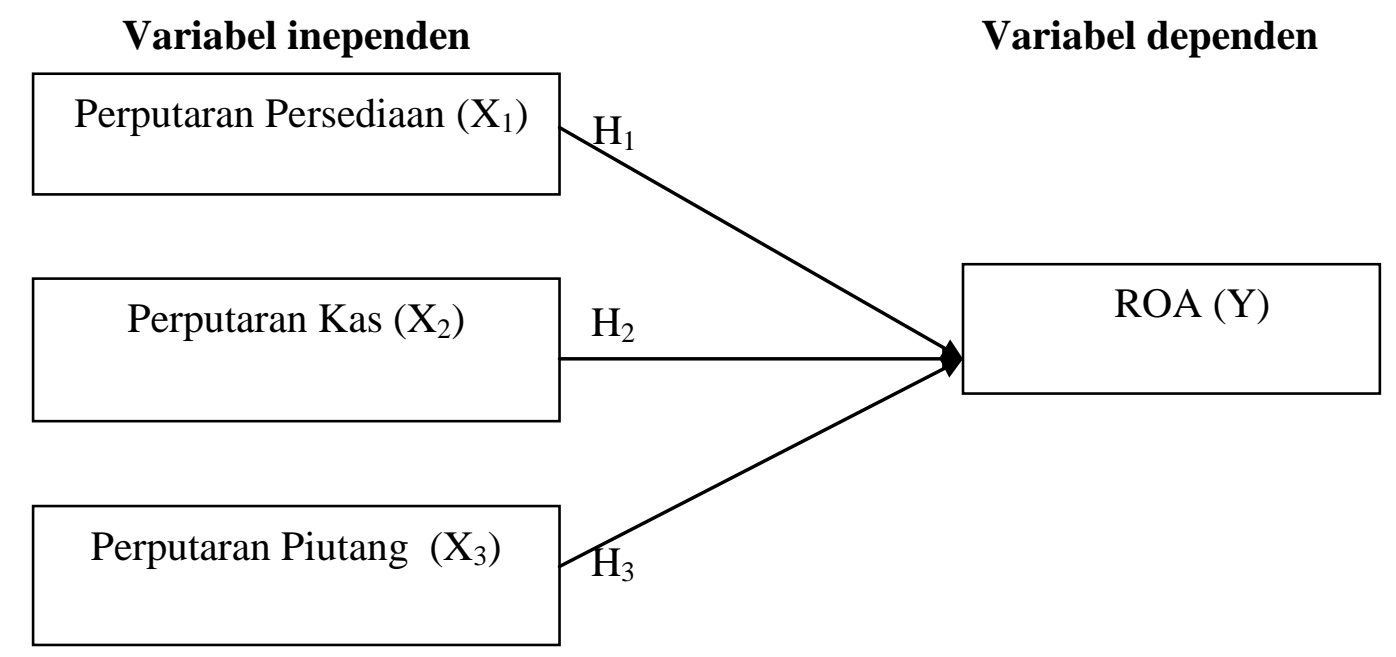

\subsection{Hipotesis}

$\mathrm{H}_{1} \quad$ : Perputaran persediaan berpengaruh terhadap rentabilitas ekonomis.

$\mathrm{H}_{2} \quad$ : Perputaran kas berpengaruh terhadap rentabilitas ekonomis.

$\mathrm{H}_{3} \quad$ : Perputaran piutang berpengaruh terhadap rentabilitas ekonomis. 


\section{METODE PENELITIAN}

\subsection{Jenis Penelitian}

Jenis penelitian yang digunakan adalah penelitian kuantitatif dengan menggunakan metode penelitian asosiatif dengan bentuk pola hubungan yaitu hubungan kausal. Menurut Sugiyono (2016: 62) Hubungan kausal adalah hubungan yang bersifat sebab akibat.

\subsection{Tempat dan Waktu Penelitian}

Dilakukan di Bursa Efek Indonesia cabang Kota Manado Galeri Investasi Fakultas Ekonomi dan Bisnis Universitas Sam Ratulangi di Manado. Dari bulan Maret sampai bulan November.

\subsection{Prosedur Penelitian}

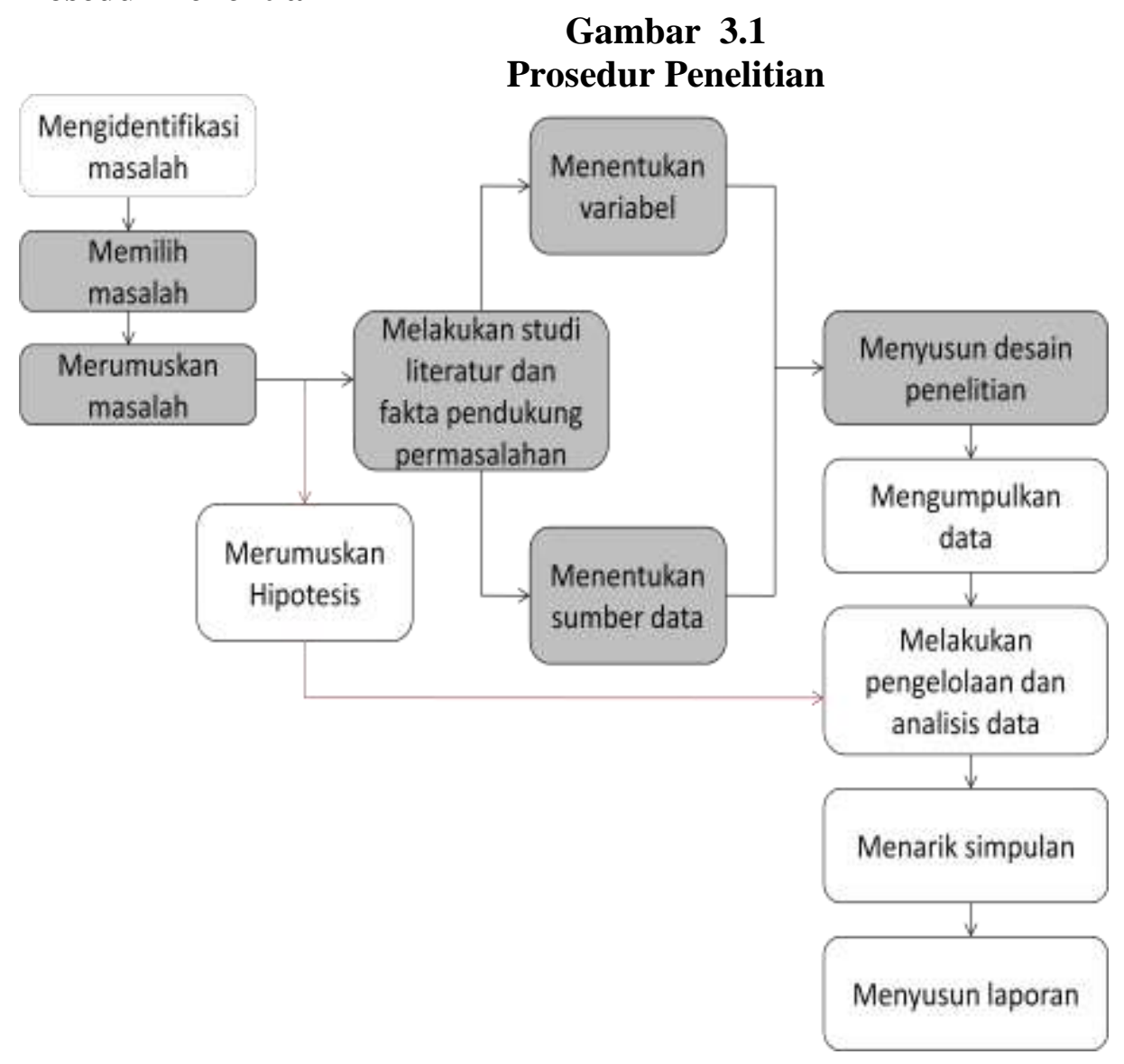

\subsection{Poputasi dan Sampel}

Menurut (Sugiyono, 2016 : 119) Populasi adalah wilayah generalisasi yang terdiri atas obyek atau subjek yang mempunyai kualitas dan karakteristik tertentu yang ditetapkan oleh peneliti untuk dipelajari dan kemudian ditarik kesimpulannya. Adapun populasi pada penelitian ini adalah Perusahaan Manufaktur yang terdaftar dibursa Efek Indonesia (BEI) yang berjumlah 144 perusahaan dan untuk sub sektor Food and Beverages berjumlah 16 perusahaan.

Menurut (Sugiyono 2016 : 125). Sampel adalah bagian dari jumlah dan karakteristik yang dimiliki oleh populasi tersebut. Penentuan sampel dalam penelitian ini dilakukan dengan metode purposive sampling. Menurut Sugiyono (2012), sampel adalah sebagian dari jumlah dan karakteristik yang dimiliki oleh populasi. Sampel dalam penelitian ini berjumlah 11 perusahaan Manufaktur sub sekotor Food and Beverages.

Adapun yang menjadi kriteria sampel yang digunakan, antara lain: 
1. Perusahaan tersebut adalah perusahaan yang bergerak pada bidang menufaktur sub sektor food and beverages terdaftar di BEI tahun 2012-2016.

2. Perusahaan-perusahaan tersebut memperoleh laba pada tahun 2012-2016.

3. Perusahaan tersebut memiliki laporan keuangan yang lengkap dan telah diaudit selama tahun 2012-2016.

4. Perusahaan tersebut memiliki data tentang persediaan, kas, dan piutang yang lengkap dari tahun 2012-2016.

\subsection{Jenis Data}

3.7 Metode Analisis

Metode analisis data yang digunakan dalam penelitian ini adalah statistik deskriptif dengan menggunakan analisis regresi linear berganda uji statistik yang digunakan untuk menjalankannya. Metode analisis dilakukan dengan bantuan software Statistic Program Service Solution (SPSS) versi 16 untuk Windows, yaitu program komputer yang khusus dibuat untuk mengelolah data secara statistik.

\subsection{Definisi dan Pengukuran Variabel}

Dalam penelitian ini terdapat dua variabel yang digunakan yaitu variabel bebas perputaran persediaan (X1), perputaran kas (X2), perputaran piutang (X3), dan variabel terikat rentabilitas ekonomis (Y).

\section{HASIL PENELITIAN DAN PEMBAHASAN}

\subsection{Gambaran Umum Objek Penelitian}

Objek dalam penelitian ini merupakan perusahaan manufaktur sub sektor Food and Bevarages yang terdaftar di Bursa Efek Indonesia pada periode 2012-2016. Perusahaan manufaktur adalah perusahaan yang melakukan aktivitas industri untuk mengelolah bahan mentah menjadi bahan jadi yang akan di jual belikan di pasaran.

\subsubsection{Sub Sektor Food and Beverages}

Perkembangan perusahaan-perusahaan food and beverages mengalami peningkatan yang cukup signifikan dan masih akan terus berkembang di masa yang akan datang. Minat investasi para investor baik dari dalam dan luar negeri terus meningkat terhadap industri food and bevarages. Seb sektor industri food and bevarages memberikan sumbangsih cukup besar kaitannya dengan penanaman modal asing (PMA).

\subsection{Pegujian Asumsi Klasik}

Sebelum melakukan analisis regresi linier berganda, data diuji terlebih dahulu dengan pengujian asumsi klasik dengan tujuan untuk mendapatkan model regresi yang baik, yang harus terbebas dari Multikolinieritas, Heteroskedastisitas, dan Normalitas.

1. Uji normalitas dilakukan untuk mengetahui apakah model regresi, variabel dependen dan independen atau keduanya berdistribusi normal atau mendekati normal. Pengujian dilakukan menggunakan analisis Kolmogorov-Smirnov (KS) dengan pengambilan keputusan jika nilai signifikan lebih besar dari 0,05 maka data tersebut berdistribusi normal. Hasil uji normalitas diperoleh sebagai berikut : 


\section{Tabel 4.1}

Uji Normalitas Kolmogorov- Smirnov

One-Sample Kolmogorov-Smirnov Test

\begin{tabular}{|ll|l|}
\hline & & Unstandardized \\
Residual
\end{tabular}

Sumber : Hasil olah data SPSS

Berdasarkan hasil uji statistik dengan Kolmogrov-Smirnov seperti yang terdapat dalam tabel 4.2 dapat disimpulkan bahwa data tidak terdistribusi normal. Hal ini dapat dilihat dari nilai Asymp.Sig.(2 tailed) adalah 0.035, karena 0,035 < 0,05 . Ada beberapa cara mengubah model regresi menjadi normal yaitu dengan melakukan transformasi data. Untuk mengubah nilai residual agar berdistribusi normal, penelitian melakukan transformasi data ke model logaritma natural (Ln) yaitu dari persamaan ROA $=\mathrm{f}$ (Ln_Perputaran persediaan, Ln_Perputaran kas, dan Ln_Perputaran piutang). Setelah itu data diuji ulang berdasarkan asumsi normalitas.

Hasil uji normalitas setelah dilakukan transformasi yang tidak normal tersebut dapat dilihat sebagai berikut:

Tabel 4.2

\section{Uji Normalitas Kolmogorov- Smirnov}

\begin{tabular}{|ll|l|}
\hline \multicolumn{2}{|c|}{ One-Sample Kolmogorov-Smirnov Test } \\
\hline N & $\begin{array}{l}\text { Unstandardized } \\
\text { Residual }\end{array}$ \\
Normal Parameters ${ }^{\mathrm{a}}$ & Mean & 49 \\
& Std. Deviation & .0000000 \\
Most Extreme Differences & Absolute & .82077484 \\
& Positive & .070 \\
& Negative & .070 \\
Kolmogorov-Smirnov Z & & -.055 \\
Asymp. Sig. (2-tailed) & .491 \\
\hline a. Test distribution is Normal. & .969 \\
\hline
\end{tabular}

Sumber : Hasil olah data SPSS.

Berdasarkan hasil uji statistik dengan model Kolmogorov-Smirnov seperti yang terdapat dalam table 4.3 dapat disimpulkan bahwa data terdistribusi normal. Hal ini dapat dilihat dari nilai Asymp.Sig. (2 tailed) Kolmogorov-Smirnov adalah 0.817 , karena $0,969>0,05$.

1. Uji Multikolinearitas, dapat dideteksi dengan menggunakan nilai VIF (Variance Inflation Factor) dan tolerance. Suatu data dikatakan tidak terdapat multikolineritas adalah apabila angka hasil olahan tolerance $>0,10$ dan VIF $<10$. 
Dari hasil pengujian uji multikolinerias diperoleh hasil untuk masing - masing variabel sebagai berikut:

Tabel 4.3

Hasil Uji Multikolinearitas

\begin{tabular}{|c|c|c|c|c|c|c|c|c|}
\hline \multicolumn{9}{|c|}{ Coefficients $^{a}$} \\
\hline \multirow{2}{*}{\multicolumn{2}{|c|}{ Model }} & \multicolumn{2}{|c|}{$\begin{array}{l}\text { Unstandardized } \\
\text { Coefficients }\end{array}$} & \multirow{2}{*}{$\begin{array}{c}\begin{array}{c}\text { Standardized } \\
\text { Coefficients }\end{array} \\
\text { Beta }\end{array}$} & \multirow[b]{2}{*}{$\mathrm{t}$} & \multirow[b]{2}{*}{ Sig. } & \multicolumn{2}{|c|}{ Collinearity Statistics } \\
\hline & & B & Std. Error & & & & Tolerance & VIF \\
\hline \multirow[t]{4}{*}{1} & (Constant) & 1.482 & .495 & & 2.992 & .004 & & \\
\hline & $\begin{array}{l}\text { Ln_Perputaran } \\
\text { persediaan }\end{array}$ & .350 & .140 & .446 & 2.494 & .016 & .527 & 1.896 \\
\hline & Ln_Perputaran kas & .273 & .095 & .440 & 2.866 & .006 & .713 & 1.404 \\
\hline & Ln Perputaran piutang & .239 & .251 & .150 & .954 & .345 & .679 & 1.472 \\
\hline
\end{tabular}

Sumber : Hasil Olah data dengan aplikasi SPSS

Dari tabel diatas menunjukkan tidak ada variabel bebas yang memiliki nilai tolerance kurang dari 0,10 . Hasil perhitungan nilai VIF juga menunjukkan tidak ada variabel bebas yang memiliki nilai VIF lebih dari 10. Jadi dapat disimpulkan bahwa tidak ada multikolineritas antara variabel bebas dalam model regresi.

2. Uji Heterokedastitas,

Cara mendetekti ada tidaknya gejala heterokedastitas adalah dengan melihat grafik scatterplot yang dihasilkan dari pengolahan data menggunakan program SPSS. Dasar pengambilan keputusan sebagai berikut :

1) Jika ada pola tertentu, seperti titik-titik yang membentuk pola tertentu yang teratur (bergelombang, melebar kemudian menyempit), maka mengidikasikan telah terjadi heterokedastitas.

2) Jika tidak ada pola yang jelas, serta titik-titik menyebar di atas dan di bawah angka 0 pada sumbu $\mathrm{Y}$, maka tidak terjadi heterokedastitas.

Berikut ini dilampirkan grafik scatterplot untuk menganalisis apakah terjadi gejala heterokedastitas atau tidak dengan cara mengamati penyebaran titik-titik pada grafik. 


\section{Gambar 4.1}

\section{Hasil Uji Heterokedastitas}

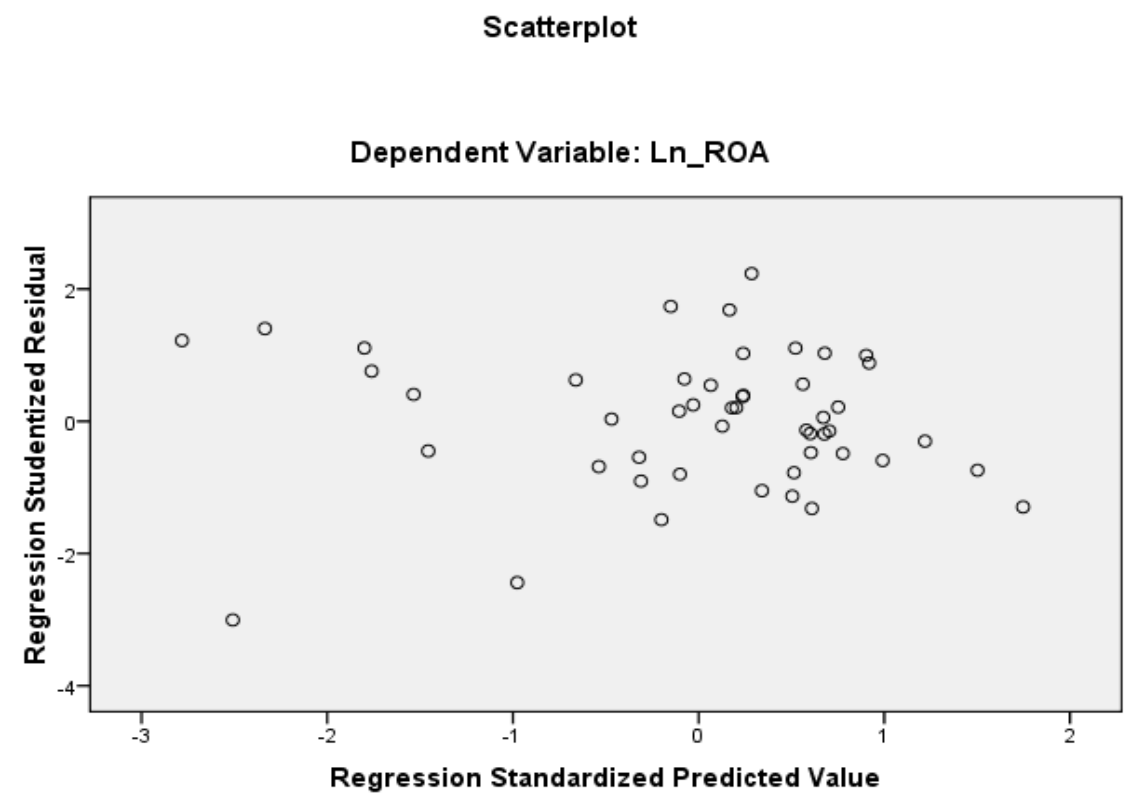

Sumber : Hasil Olah data dengan aplikasi SPSS

Dari grafik scatterplot terlihat bahwa titik-titik menyebar secara acak dengan titik tidak adanya pola yang jelas serta tersebar baik diatas maupun dibawah angka 0 pada sumbu Y. Dengan demikian, dapat disimpulkan bahwa tidak terjadi heterokedastitas sehingga model ini layak dipakai untuk mengetahui pengaruh terhadap rentabilitas ekonomis pada perusahaan manufaktur yang terjadi di Bursa Efek Indonesia berdasarkan masukan variabel independen yaitu perputaran persediaan, perputaran kas dan perputaran piutang.

3. Uji Autokorelasi

Dalam penelitian ini, uji autokorelasi dilakukan dengan melihat nilai Durbun Watson $(D-W)$. Cara mendeteksi apakah model yang digunakan mengalami gejala autokorelasi adalah dengan melihat nilai statistik Durbin Watson. Hasil uji autokorelasi dapat dilihat pada tabel berikut ini :

Tabel 4.4

\section{Hasil Uji Autokorelasi}

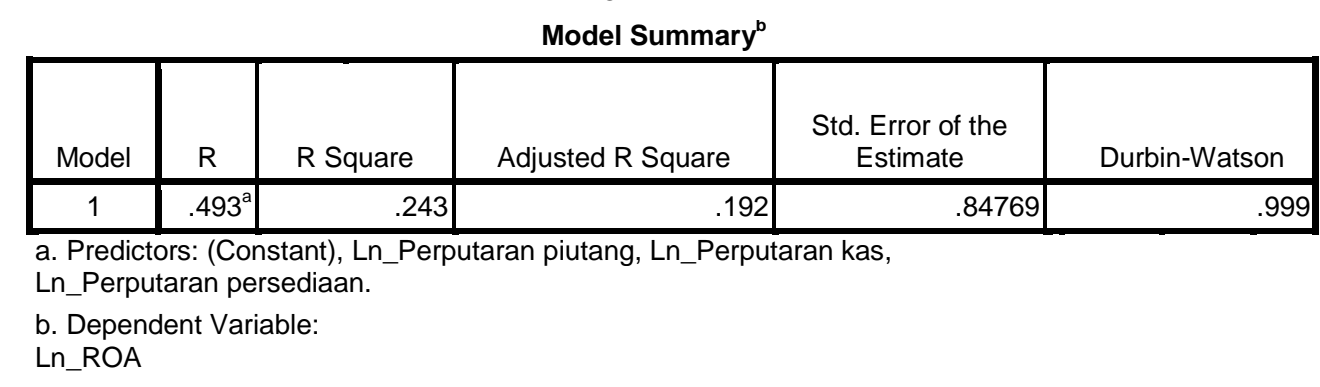

Sumber : Hasil Olah data dengan aplikasi SPSS 
Berdasarkan hasil pengujian diperoleh bahwa tidak terjadi autokorelasi antar kesalahan pengganggu antar periode. Hal ini dilihat dari nilai Durbin-Watson (DW) sebesar 0,999. Angka tersebut berada diantar -2 dan +2 , artinya bahwa angka DW lebih besar dari -2 dan lebih kecil dari $+2(-2<0,867<+2)$. Jadi dapat disimpulkan bahwa tidak ada autokorelasi positif maupun negatif.

\subsection{Uji Statistik}

1. Uji Koefisien Determinasi

Tabel 4.6

\section{Uji Koefisien Determinasi}

\begin{tabular}{|c|c|c|c|c|c|}
\hline \multicolumn{6}{|c|}{ Model Summary ${ }^{\mathrm{D}}$} \\
\hline Model & $\mathrm{R}$ & R Square & Adjusted R Square & $\begin{array}{l}\text { Std. Error of the } \\
\text { Estimate }\end{array}$ & Durbin-Watson \\
\hline 1 & $.493^{\mathrm{a}}$ & .243 & .192 & .84769 & .999 \\
\hline \multicolumn{6}{|c|}{$\begin{array}{l}\text { a. Predictors: (Constant), Ln_Perputaran piutang, Ln_Perputaran kas, } \\
\text { Ln_Perputaran persediaan. }\end{array}$} \\
\hline $\begin{array}{l}\text { b. Depen } \\
\text { Ln_ROA }\end{array}$ & t Var & & & & \\
\hline
\end{tabular}

Sumber : Hasil Olah data dengan aplikasi SPSS

Dari hasil perhitungan Pengujian Koefisien Determinasi $\left(\mathrm{R}^{2}\right)$ didapat nilai $R$-Square sebesar 0,243 atau $24 \%$ artinya pengaruh perputaran persediaan, perputaran kas, dan perputaran piutang mempunyai pengaruh sebesar $24 \%$ terhadap rentabilitas ekonomis sedangkan sisanya sebesar $76 \%$ dipengaruhi oleh faktor lain yang tidak diteliti.

2. Uji Koefisien Regresi (Uji t)

Tabel 4.7

\section{Uji Statistik T}

\begin{tabular}{|c|c|c|c|c|c|c|c|c|}
\hline \multicolumn{9}{|c|}{ Coefficients $^{a}$} \\
\hline \multirow{2}{*}{\multicolumn{2}{|c|}{ Model }} & \multicolumn{2}{|c|}{$\begin{array}{l}\text { Unstandardized } \\
\text { Coefficients }\end{array}$} & \multirow{2}{*}{$\begin{array}{c}\begin{array}{c}\text { Standardized } \\
\text { Coefficients }\end{array} \\
\text { Beta }\end{array}$} & \multirow[b]{2}{*}{$\mathrm{t}$} & \multirow[b]{2}{*}{ Sig. } & \multicolumn{2}{|c|}{ Collinearity Statistics } \\
\hline & & B & Std. Error & & & & Tolerance & VIF \\
\hline \multirow[t]{4}{*}{1} & (Constant) & 1.482 & .495 & & 2.992 & .004 & & \\
\hline & Ln_Perputaran persediaan & .350 & .140 & .446 & 2.494 & .016 & .527 & 1.896 \\
\hline & Ln_Perputaran kas & .273 & .095 & .440 & 2.866 & .006 & .713 & 1.404 \\
\hline & Ln_Perputaran piutang & .239 & .251 & .150 & .954 & .345 & .679 & 1.472 \\
\hline
\end{tabular}

Sumber: Output SPSS diolah peneliti 
3. Uji Anova (Uji f)

\section{Hasil Uji F}

ANOVA $^{\mathrm{D}}$

\begin{tabular}{|c|c|c|c|c|c|c|}
\hline \multicolumn{2}{|c|}{ Model } & Sum of Squares & Df & Mean Square & $\mathrm{F}$ & Sig. \\
\hline 1 & Regression & 10.363 & 3 & 3.454 & 4.807 & $.005^{\mathrm{a}}$ \\
\hline & Residual & 32.336 & 45 & .719 & & \\
\hline & Total & 42.700 & 48 & & & \\
\hline
\end{tabular}

a. Predictors: (Constant), Ln_Perputaran piutang, Ln_Perputaran kas, Ln_Perputaran

persediaan

b. Dependent Variable: Ln_ROA

Sumber: Output SPSS diolah peneliti

Hasil uji $\mathrm{F}$ yang ditampilkan dalam table 4.9 menunjukan bahwa nilai $\mathrm{F}_{\text {hitung }}$ adalah 4,807 dengan tingkat signifikansi $0,005(<0,05)$. Dengan mengunakan table $\mathrm{F}$ diperoleh nilai $F_{\text {tabel }}$ sebesar 2,77. Hal ini menunjukan bahwa nilai $F_{\text {hitung }}>F_{\text {tabel }}$ yang berarti bahwa $\mathrm{H}_{1}$ diterima dan $\mathrm{H}_{0}$ ditolak, artinya variabel bebas perputaran persediaan, perputaran kas, dan perputaran piutang secara simultan berpengaruh secara signifikan terhadap rentabilitas ekonomis pada perusahaan manufaktur yang terdaftar di Bursa Efek Indonesia.

\subsection{Analisis Regresi Linier Berganda}

Tabel 4.5

Koefisien Regresi

\section{Coefficients $^{\mathrm{a}}$}

\begin{tabular}{|c|c|c|c|c|c|c|c|c|}
\hline & \multirow[b]{2}{*}{ Model } & \multicolumn{2}{|c|}{$\begin{array}{l}\text { Unstandardized } \\
\text { Coefficients }\end{array}$} & \multirow{2}{*}{$\begin{array}{c}\text { Standardized } \\
\text { Coefficients }\end{array}$} & \multirow[b]{2}{*}{$\mathrm{t}$} & \multirow[b]{2}{*}{ Sig. } & \multicolumn{2}{|c|}{ Collinearity Statistics } \\
\hline & & B & Std. Error & & & & Tolerance & VIF \\
\hline \multirow[t]{4}{*}{1} & (Constant) & 1.482 & .495 & & 2.992 & .004 & & \\
\hline & $\begin{array}{l}\text { Ln_Perputaran } \\
\text { persediaan }\end{array}$ & .350 & .140 & .446 & 2.494 & .016 & .527 & 1.896 \\
\hline & Ln_Perputaran kas & .273 & .095 & .440 & 2.866 & .006 & .713 & 1.404 \\
\hline & Ln Perputaran piutang & .239 & .251 & .150 & .954 & .345 & .679 & 1.472 \\
\hline
\end{tabular}

a. Dependent Variable: Ln_ROA

Sumber : Hasil Olah data dengan aplikasi SPSS

Berdasarkan table koefisien diatas, pada kolom unstanddardized coefficients bagian $\mathrm{B}$ diperoleh model permasalahan regresi linear berganda sebagai berikut :

$$
\mathrm{Y}=1.482+0,350\left(\mathrm{X}_{1}\right)+0,273\left(\mathrm{X}_{2}\right)+0,239\left(\mathrm{X}_{3}\right)+\mathrm{e}
$$

Dimana :

$\mathrm{Y}=$ Return On Assets (ROA)

$\mathrm{X}_{1}=$ Perputaran persediaan

$\mathrm{X}_{2}=$ Perputaran kas

$\mathrm{X}_{3}=$ Perputaran piutang

$\mathrm{e}=$ Error 
Pada Unstandardized coefficients, diperoleh nilai $\mathrm{a}, \mathrm{b}_{1}, \mathrm{~b}_{2}$, sebagai berikut:

a. Nilai B Constant $(\alpha)=1,482=$ konstanta

Nilai konstanta ini menunjukan bahwa apabila tidak ada nilai variabel bebas yaitu perputaran persediaan, persediaan kas, dan persediaan piutang, maka perubahan nilai rentabilitas ekonomis yang dilihat dari nilai Y tetap sebesar 1,482.

b. Nilai $b_{1}=0.350=$ perputaran persediaan

Koefisien regresi ini menunjukan bahwa setiap kenaikan perputaran persediaan sebesar $1 \%$, maka perubahan rentabilitas ekonomis yang dilihat dari nilai Y akan bertambah sebesar 0,350 dengan asumsi variabel lain dianggap tetap.

c. $\quad$ Nilai $b_{1}=0.273=$ perputaran kas

Koefisien regresi ini menunjukan bahwa setiap kenaikan perputaran kas sebesar $1 \%$, maka perubahan rentabilitas ekonomis yang dilihat dari nilai Y akan bertambah sebesar 0,273 dengan asumsi variabel lain dianggap tetap.

d. $\quad$ Nilai $b_{1}=0,239=$ perputaran piutang

Koefisien regresi ini menunjukan bahwa setiap kenaikan perputaran piutang sebesar $1 \%$, maka perubahan rentabilitas ekonomis yang dilihat dari nilai Y akan bertambah sebesar 0,239 dengan asumsi variabel lain dianggap tetap.

\subsection{Pembahasan}

\subsubsection{Pengaruh Perputaran Persediaan Terhadap Rentabilitas Ekonomis}

Dari hasil penelitian ini menyimpulkan Perputaran persediaan berpengaruh signifikan terhadap Rentabilitas. Hal ini dapat dilihat dari hasil pengujian secara parsial (Uji t) pada table 4.8 Terlihat pada kolom Perputaran Persediaan $\left(\mathrm{X}_{1}\right)$ terhadap nilai sig. 0,016. Nilai sig lebih kecil dari nilai probabilitas 0,05 atau nilai $0,016<0,05$, maka hasil hipotesisnya adalah $\mathrm{H}_{\mathrm{a}}$ diterima dan $\mathrm{H}_{0}$ ditolak. Variabel $\mathrm{X}_{1}$ mempunyai nilai $\mathrm{t}_{\text {hitung }}$ yakni 2,494 dengan $t$ table $=2,004$. Yang berarti nilai $t_{\text {hitung }}>t_{\text {tabel }}$ dapat disimpulkan bahwa variabel $\mathrm{X}_{1}$ memiliki konstribusi terhadap $\mathrm{Y}$. Nilai t positif menunjukkan bahwa variabel $\mathrm{X}_{1}$ mempunyai hubungan yang searah dengan $\mathrm{Y}$.

Jadi dapat disimpulkan bahwa perputaran persediaan memiliki pengaruh signifikan terhadap Rentabilitas ekonomis. Dan dari hasil penelitian ini juga didapat persamaan transformasi regresi linear sebagai berikut $\mathrm{ROA}=1,482+0,350\left(\mathrm{X}_{1}\right)+0,273\left(\mathrm{X}_{2}\right)+-0,239$ $\left(X_{3}\right)+$ e Nilai koefisien perputaran persediaan untuk variabel $X_{1}$ sebesar kenaikan perputaran persediaan satu tahunan maka variabel ROA akan naik sebesar 0,350 dengan asumsi bahwa yang lain dari model regresi adalah tetap.

Murhadi (2013: 59) rasio perputaran persediaan (inventory turnover) mengidentifikasi efisien perusahaan dalam memproses, dan mengelola persediaannya. Secara teoritis, apabila tingkat perputaran semakin tinggi, maka semakin rendah tingkat resiko yang akan terjadi dan jumlah persediaan tidak terlalu besar. Resiko yang dimaksud seperti dalam penurunan harga, biaya pemeliharaan, biaya penyimpanan, dan selera konsumen. Hasil penelitian ini didukung oleh penelitian dari Suryani (2016) hasil uji secara parsial perputaran persediaan berpengaruh signifikan terhadap rentabilitas ekonomi.

\subsubsection{Pengaruh Perputaran Kas Terhadap Rentabilitas Ekonomis}

Dari hasil pengujian (Uji t) menyimpulkan perputaran kas berngaruh signifikan terhadap Rentabilitas ekonomis pada perusahaan manufaktur sub sektor food and beverages 
pada tahun 2012-2016, terlihat pada Tabel 4.8 Kolom perputaran kas dengan nilai sig 0,006 nilai sig lebih kecil dari nilai probabilitas 0,05, atau nilai $0,006<0,05$ maka hasil hipotesisnya adalah $\mathrm{Ha}$ diterima dan Ho ditolak. Variabel $\mathrm{X}_{2}$ mempunyai $\mathrm{t}$ hitung yakni 2,866 dengan $t_{\text {tabel }}=2,004$. Jadi $t_{\text {hitung }}>t_{\text {tabel }}$ maka dapat disimpulkan bahwa perputaran piutang berpengaruh signifikan terhadap ROA.

Jadi dapat disimpulkan bahwa perputaran persediaan memiliki pengaruh signifikan terhadap Rentabilitas ekonomis. Dan dari hasil penelitian ini juga didapat persamaan transformasi regresi linear sebagai berikut ROA $=1,482+0,350\left(X_{1}\right)+0,273\left(X_{2}\right)+0,239$ $\left(X_{3}\right)+$ e Nilai koefisien perputaran persediaan untuk variabel $X_{1}$ sebesar kenaikan perputaran persediaan satu tahunan maka variabel ROA akan naik sebesar 0,350 dengan asumsi bahwa yang lain dari model regresi adalah tetap.

Menurut Riyanto (2012: 95) menyatakan semakin tinggi tingkat perputaran kas berarti semakin efisien tingkat penggunaan kasnya. Sebaliknya semakin rendah tingkat perputarannya semakin tidak efisien, karena semakin banyaknya uang yang berhenti atau tidak dipergunakan. Hal ini berarti perusahaan telah menggunakan kas secara efisien, sehingga semakin tinggi tingkat perputaran kas berarti semakin cepat kembalinya kas masuk pada perusahaan. Dengan demikian kas akan dapat dipergunakan lagi untuk membiayai kegiatan operasional sehingga laba yang diterima perusahaan menjadi besar. Hasil penelitian ini didukung oleh penelitian dari Agustini, dkk (2014) Perputaran kas berpengaruh signifikan terhadap rentabilitas ekonomis.

\subsubsection{Pengaruh Perputaran Piutang Terhadap Rentabilitas Ekonomis}

Dari hasil pengujian (Uji t) menyimpulkan perputaran piutang tidak memiliki pengaruh yang signifikan terhadap Rentabilitas ekonomis pada perusahaan manufaktur sub sektor food and beverages pada tahun 2012-2016, terlihat pada Tabel 4.8 Kolom perputaran piutang dengan nilai sig 0,345 nilai sig lebih besar dari nilai probabilitas 0,05 , atau nilai 0,345 > 0,05 maka hasil hipotesisnya adalah Ha ditolak dan Ho diterima. Variabel $\mathrm{X}_{3}$ mempunyai $\mathrm{t}$ hitung yakni 0,954 dengan $\mathrm{t}_{\text {tabel }}=2$,004. Jadi $t_{\text {hitung }}<\mathrm{t}_{\text {tabel }}$ maka dapat disimpulkan bahwa perputaran piutang tidak berpengaruh signifikan terhadap ROA. Dan dari hasil penelitian didapat persamaan transformasi regresi linear sebagai berikut : $\mathrm{ROA}=1,482$ $+0,350\left(X_{1}\right)+0,273\left(X_{2}\right)+0,239\left(X_{3}\right)+$ e. Nilai koefisien perputaran piutang untuk variabel $\mathrm{X}_{3}$ sebesar 0,239 dan bertanda negatif. Hal ini mengandung arti bahwa setiap kenaikan perputaran piutang satu tahunan maka variabel ROA akan turun sebesar 0,239 dengan asumsi bahwa variabel yang lain dari model regresi adalah tetap.

Menurut Kasmir (dalam Tirtaiaya 2015) Piutang sebagai unsur modal kerja dalam kondisi berputar, yaitu dari kas, proses komoditi, penjualan, piutang dan kembali ke kas. Makin cepat perputaran makin baik kondisi keuangan perusahaan. Periode perputaran piutang tergantung pada panjang pendeknya ketentuan waktu yang dipersyaratkan dalam syaratkan dalam syarat pembayaran kredit. Disisi lain, syarat pembayaran kredit juga akan mempengaruhi tingkat perputaran piutang dimana tingkat perputaran piutang menggambarkan berapakali modal yang tertanam dalam piutang berputar dalam satu tahun (Irman, 2014). Hal ini menunjukan piutang dalam perusahaan banyak yang belum terbayarkan atau piutang yang sudah lewat masa pembayaran telah dihapus oleh pihak perusahaan, sehingga mengakibatkan biaya pengumpulan piutang dan biaya sumber dana semakin besar dan tentu saja akan mengurangi laba atau mungkin karena bagian kredit dan penagihan bekerja tidak efektif. Penelitian ini didukung oleh penelitian yang dilakukan oleh Haq (2013) Perputaran piutang tidak berpengaruh signifikan terhadap rentabilitas ekonomi. 


\subsubsection{Pengaruh Peputaran Persediaan, Perputaran Kas, dan Perputaran Piutang Terhadap Rentabilitas Ekonomis}

Dari hasil penelitian ini Perputaran persediaan, Perputaran kas dan Perputaran Piutang secara bersamaan memiliki pengaruh yang signifikan terhadap Rentabilitas Ekonomis pada perusahaan Manufaktur Sub Sektor Food and Beverages di Bursa Efek Indonesia. Hal ini dapat dilihat dari tabel 4.9 Uji $\mathrm{F}$ dan hasil yang diperoleh menunjukan bahwa nilai $F_{\text {hitung }}$ dengan $F_{\text {tebel }}$ adalah $4,807>2,77$ berarti hasil untuk hipotesisnya Ho dan Ha diterima. Artinya perputaran persediaan, perputaran kas dan perputaran piutang secara bersama-sama berpengaruh signifikan terhadap tingkat rentabilitas ekonomis. Hal ini menunjukan pentingnya pengelolaan perputaran persediaan, perputaran kas, dan perputaran piutang secara efektif, guna untuk mempengaruhi rentabilitas ekonomis dalam suatu perusahaan. Penelitian ini didukun oleh penelitian yang di lakukan oleh Rahayu dan Susilowibowo (2014) Perputaran persediaan, perputaran kas dan perputaran piutang berpengaruh terhadap rentabilitas ekonomis.

Sementara itu dari hasil analisis koefisien determinasi $\left(\mathrm{R}^{2}\right)$ tabel 4.7 dari tabel tersebut didapat nilai ( $R$ Square) dengan nilai 0,243 yang berarti perputaran persediaan, perputaran kas, dan perputaran piutang mempunyai pengaruh sebesar $24 \%$ terhadap tingkat rentabilitas ekonomis sedangkan sisanya $76 \%$ dijelaskan oleh faktor lainnya, yang tidak diteliti dalam penelitian ini.

\section{KESIMPULAN DAN SARAN}

\subsection{Kesimpulan}

Penelitian ini bertujuan menganalisis pengaruh perputaran persediaan, perputaran kas, dan perputaran piutang pada perusahaan manufaktur sub sektor food and beverages yang terdaftar di Bursa Efek Indonesia tahun 2012-2016. Berdasarkan hasil regresi dan analisa data, maka dapat ditarik kesimpulan bahwa :

1. Perputaran persediaan berpengaruh secara signifikan terhadap rentabilitas ekonomis. Hal ini mengindikasikan bahwa semakin tinggi tingkat perputaran persediaan dalam perusahaan maka semakin tinggi pula tingkat rentabilitas ekonomis.

2. Perputaran kas berpengaruh signifikan terhadap rentabilitas ekonomis. Hal ini mengidentifikasi bahwa semakin tinggi tingkat perputaran kas maka semakin tinggi pula tingkat rentabilitas ekonomis.

3. Perputaran piutang tidak berpengaruh signifikan terhadap rentabilitas ekonomis. Hal ini mengidentifikasi bahwa semakin tinggi tingkat perputaran piutang tidak terlalu mempengaruhi tingginya tingkat rentabilitas ekonomis dalam perusahaan.

4. Perputaran persediaan, perputaran kas dan perputaran piutang secara simultan memiliki pengaruh yang signifikan terhadap rentabilitas ekonomis.

\subsection{Saran}

Adapun saran yang dapat diberikan adalah sebagai berikut :

1. Bagi pihak internal perusahaan maupun investor disarankan untuk dapat memperhatikan perputaran persediaan, perputaran kas, dan perputaran piutang terhadap peningkatan rentabilitas ekonomis dalam keadaan cukup sehingga dapat mengambil keputusan.

2. Sebaiknya peneliti selanjutnya menggunakan sampel yang lebih banyak dengan karakteristik yang lebih beragam dari berbagai sektor manufaktur. Sehingga diketahui pengaruh perputaran persediaan, perputaran kas, dan perputaran 
piutang terhadap rentabilitas ekonomis apabila diterapkan pada perusahaan yang berbeda.

3. Bagi peneliti selanjutnya yang tertarik melakukan penelitian sejenis, dapat menambahkan variabel bebas (independen) yang lain seperti modal kerja, investasi aktiva tetap dan lain-lain, memperpanjang waktu penelitian, atau mengambil sampel dari bidang perusahaan lain seperti perusahaan jasa transportasi, perusahaan telekomunikasi, dan lain-lain.

\section{DAFTAR PUSTAKA}

Agustini, Dwi Made Ni, Bagia Wayan I. Yudiaatmaja Fridayana. 2014. Pengaruh Perputaran Kas dan Perputaran Piutang Terhadap Rentabilitas Ekonomis Pada Koperasi. Jurusan Manajemen Universitas Pendidikan Ganesha Singaraja, Indonesia: Bali. e-journal. Hal. 1-10. Vol.

Harrison, Jr, Walter T, Homgren $\mathrm{T}$ Charles, Thomas William C, dan Suwardy Themin, 2013. Akuntansi Keuangan, Jilid2, Edisi 8, Erlangga, Jakarta.

Haq, N A Deden. 2013. Pengaruh Perputaran Piutang dan Perputaran Persediaan Terhadap Tingkat Return On Assets (ROA) Pada PT. HM Sampoerna, Tbk. Skripsi. Program Studi Manajemen. Fakultas Ekonomi. Universitas Islam Negeri Sunan Gunung Djati Bandung.

Irman, Deni. 2014. Pengaruh Tingkat Perputaran Kas, Perputaran Piutang, Dan Perputaran Persediaan Terhadap Profitabilitas Pada Perusahaan Manufaktur Yang Terdaftar Di Bursa Efek Indonesia Periode 2009-2011. Skripsi. Fakultas Ekonomi. Universitas Maritim Raja Ali Haji. Semarang.

Kasmir. 2015. Analisis Laporan Keuangan. PT Raja Grafindo Persada. Jakarta.

Rahayu, Eka Ayu dan Susilowibowo Joni. 2014. Pengaruh Perputaran Kas, Perputaran piutang dan Perputaran Persediaan Terhadap Profitabilitas Perusahaan Manufaktur. Vol.2 No.4. hal. 1444.1455.

Riyanto, Bambang. 2011. Dasar-dasar Pembelanjaan Perusahaan. BPFE. Yogyakarta.

Riyanto, Bambang. 2012 "Dasar-dasar Pembelajaran Perusahaan”, BPFE. Yogyakarta,

Sugiyono. 2016. Metode Penelitian Kuantitatif Kualitatif dan R\&B. Cetakan Ke- 23. Alfabeta. Bandung.

Suryani, Arna. 2016. Analisis Pengaruh Tingkat Perputaran Piutang dan Tingkat Perputaran Persediaan Terhadap Rentabilitas Ekonomi Pada PT. Afresh Indonesia Jambi. Jurnal Ilmia Universitas Batanghari. Hal.17-22. Jambi Vol.16 No.1.

Wahyudiono, Bambang. 2014. Mudah Membaca Laporan Keuangan. Raih Asa Sukses Swadaya Grup. Jakarta.

Zulfikar. 2016. Pengantar Pasar Modal Dengan Pendekatan Statistika. CV Budi Utama. Yogyakarta. 